\title{
The Foreign Exchange Content of Kenyan Agriculture ${ }^{1}$
}

\section{Jennifer Sharpley}

\section{Introduction}

This Kenyan case study focuses on three issues which may be of general interest in the discussion of cash crops and macroeconomic management. They are (a) the size and nature of the imported inputs used in the production, processing and transport of domestic and export agriculture; (b) the average import content of major food and non-food crops; and (c) the net foreign exchange contribution of the agricultural sector towards the balance of payments, and interdependence between agricultural export earnings and imported inputs needed for domestic food production.

Throughout, 'cash crops' refers to agricultural commodities sold through parastatal marketing boards and traded privately by individuals, companies and estates. No attempt has been made to estimate the imported inputs used in agricultural production for on-farm consumption and that traded in local village markets, but the imported inputs used in these items are thought to be relatively small. The estimates are based on a lengthy study of foreign exchange issues and the agricultural sector commissioned by the Government of Kenya, from which several tables are reproduced with permission. Data on the value of agricultural inputs and sales were obtained mainly from financial controllers and accountants in numerous firms, parastatals, and estates contacted during nine months of field work carried out during 1984-85. The data were usually from audited income and expenditure statements, and the financial year 1983/84 was the most recent twelve month period for which information was available.

The agricultural sector was defined broadly and includes not only on-farm production but also transportation and processing. Input data were collected for each major cash crop:

$\begin{array}{ll}\text { production } & \text { fertiliser, agrochemicals, hand } \\ \text { inputs } & \begin{array}{l}\text { tools, tractors, field machinery, } \\ \text { field vehicles, petrol and oil, bags, }\end{array} \\ & \begin{array}{l}\text { seeds. } \\ \text { processing machinery, fuel oil, } \\ \text { electricity, processing ingredients, } \\ \text { inputs }\end{array} \\ & \text { packaging. }\end{array}$

The views expressed are those of the writer and do not necessarily reflect those of the Government of Kenya. transport trucks and lorries, railways.

Information with which to estimate expatriate management fees, the repatriation of profits and dividends by foreign companies, or the cost of foreign borrowing by agricultural parastatals was not avaiable. Owing to the difficulties encountered in estimating depreciation, the foreign exchange estimates for processing machinery are thought to be understated, and this mainly affects sugar and cereal milling. The foreign exchange costs of storage facilities, and of transporting domestic commodities from the factory or store to the final consumer, are not covered in the study because insufficient data were available with which to make reasonably reliable estimates. Most domestic cash crops have been estimated at the ex-store or ex-factory level, and export crops calculated at the f.o.b. level can be converted to the ex-factory or ex-store level simply by deducting transport costs from the total cost of imported inputs.

The foreign exchange content of each production, processing and transport item was estimated using information gathered from the main suppliers, supplemented with data from the import licensing schedules, official price structures, and other sources. For example, from the official price structure it was found that the cnf price of fertiliser at the port of Mombasa accounted for around 70 per cent of local retail prices. Similarly, information provided by a major petroleum company showed that the cnf value of imported crude petroleum represented 50 per cent of the sales price of petrol used by tractors, and fuel oil represented 100 per cent of the import cost, since fuel oil did not attract sales or import duties and was cross-subsidised by other petroleum items. Based on a breakdown of the import content of spare parts, repairs, renewals, and depreciation, the import content of road transport was estimat ed at 35 per cent of local transport costs.

Standard assumptions as to the average import content of each production, processing and transport item were then applied to the 1983/84 financial data, and the foreign exchange components were aggregated for the following major agricultural commodities:

export crops coffee, tea, horticulture, tinned pineapples, sisal, pyrethrum extract, cashew nuts, wattle extract.

IDS Bulletin, 1988, vol 19 no 2, Institute of Development Studies, Sussex 
cereals

maize (NCPB purchases only), wheat, barley, rice.

milling maize flour, wheat flour, animal feeds.

other domestic sugar oilseeds, tobacco, cotton. crops

\section{dairy and} livestock animal drugs and medicines, hides and skins exports, canned meat (KMC), milk products (KCC).

Separate estimates were made for coffee and tea produced on small-holdings and on estates; and horticulture exports were represented by the two major items - cut flowers and french beans. Three separate estimates were made of imported inputs used in the production and transport of maize purchased by the National Cereals and Produce Board (NCPB), with deliveries subdivided into those from: large scale mechanised farms, small mechanised farms, and small non-mechanised farms.

Comprehensive data on the value of dairy and livestock production or sales are not available in Kenya, but considerable attention was paid to estimating the cost of imported inputs for animal drugs and medicines, based on figures collected from the Department of Veterinary Supplies and all major agro-chemical suppliers of veterinary products. In addition to the imported inputs used in animal production, foreign exchange is also used in the processing and transportation of dairy and livestock products for the domestic market and for export. Unfortunately the coverage of these imported inputs for dairy and livestock commodities shown in Table 1 is far from complete, and it includes only the processing and transport costs of packaged milk products from Kenya Co-operative Creameries (KCC) and of processed meat from Kenya Meat Commission (KMC), plus the imported inputs used in processing hides and skins for export.

\section{The Size and Nature of Foreign Exchange Inputs used in Domestic and Export Agriculture}

Those imported inputs which could be identified are summarised in Table 1 by major commodity groups, with further details given in Table 2 .

As we see from Table 1, the total foreign exchange inputs for marketed agriculture in 1983/84 were estimated at Ksh $2,969 \mathrm{mn}$, or US $\$ 215 \mathrm{mn}$. As a check on the reasonableness of this figure we may wish to compare it with the total import bill and the value of agricultural production. Total foreign exchange inputs for the production, processing and transport of agricultural commodities represented 13 per cent of total visible imports in $1983 / 84$, and 13 per cent of agricultural GDP averaged over the same years, which suggests that the estimates are not excessive. Moreover, elsewhere it has been shown that the national accounts figures considerably understate the value of traditional agriculture and on-farm consumption [Sharpley 1986:23-32].

The coverage of cash crops shown in Table 1 is somewhat similar to that published in the Statistical Abstract series on 'Gross Marketed Production from Large and Small Farms', but while the GMP series records the value of marketed production of major crops, dairy and livestock sold through official parastatal marketing boards and by estates and companies, it excludes much of the value added due to transport and processing activities. The value added in processing the two major export crops, coffee and tea is included in the GMP series, but the value added from milling cereals is excluded, together with the value added from the processing, packaging and transport of canned pineapples, wattle extract, pyrethrum extract, sugar, oilseeds, tobacco, cotton, hides and skins, and milk products. Bearing in mind these differences in coverage, the estimated value of import inputs used in the production, processing and transport of agricultural cash crops covered in Table 1, represented around 25 per cent of Gross Marketed Production averaged over 1983/84.

The total size of imported inputs for agricultural cash crops in 1983/84 may have been constrained somewhat by the shortage of foreign exchange as Central Bank reserves were well below the average for 1978-81. The scarcity of foreign exchange which immediately followed the attempted coup of August 1982 markedly altered the speed with which applications for import licences were approved by the Central Bank, but by the latter half of 1983 the backlog of pending import licences had been reduced to normal proportions. In the process, priority had been given to the allocation of import licences for intermediate and capital goods rather than consumption items, and key agricultural inputs such as fertiliser and agro-chemicals, had been well protected. In December 1982, the Kenyan shilling was devalued against the SDR by around 18 per cent and it would appear that throughout most of the 1983/84 financial year, the currency was not seriously overvalued. According to figures published in Pick's Currency Yearbook [1984:44], at the end of December 1983 the official exchange rate was only 15 per cent lower than the black market rate of exchange for US dollars.

Following the failure of the long rains over parts of the country in April-June 1984, drought conditions affected the level of agricultural production in the latter part of 1984 . On the world market, tea prices reached record levels in $1983 / 84$, but the estimates in Table 1 have been corrected for this temporary boom, and the foreign exchange inputs for the production, 


\begin{tabular}{|c|c|c|c|c|c|c|c|}
\hline & & & $K$ shillin & $s$ million & & & \\
\hline & $\begin{array}{l}\text { Export } \\
\text { Crops }\end{array}$ & $\begin{array}{c}\text { Cereal } \\
\text { Production }\end{array}$ & Millingg & $\begin{array}{c}\text { Other } \\
\text { Domestic } \\
\text { Crops }\end{array}$ & $\begin{array}{c}\text { Dairy } \\
\text { and } \\
\text { Livestock } \\
\text { Products }\end{array}$ & $\begin{array}{l}\text { GRANL } \\
K \text { shs } \\
\text { million }\end{array}$ & $\begin{array}{c}\text { TOTAL } \\
\text { USS } \\
\text { million }^{\mathrm{a}}\end{array}$ \\
\hline Fertiliser & 196.2 & 204.1 & & 77.0 & & 477.3 & 34.6 \\
\hline Agro chemicals & 288.7 & 92.9 & & 47.7 & 200.0 & 629.3 & 45.6 \\
\hline Hand tools & 13.2 & & & 0.5 & & 13.7 & 1.0 \\
\hline $\begin{array}{l}\text { Tractors } \\
\text { Farm machinery } \\
\text { Farm vehicles } \\
\text { Petrol and oils }\end{array}$ & 156.6 & 101.5 & & 175.4 & & 433.5 & 31.4 \\
\hline Bags & 15.0 & 37.7 & & & & 52.7 & 3.8 \\
\hline Seeds & & 31.6 & & & & 31.6 & 2.3 \\
\hline Production sub-total & 669.6 & 467.9 & & 300.6 & 200.0 & $1,638.1$ & 118.7 \\
\hline Processing machinery & 65.7 & & 48.4 & 106.9 & 17.2 & 238.2 & 17.3 \\
\hline Fuel oil & 81.5 & & 3.2 & 30.6 & 8.9 & 124.2 & 9.0 \\
\hline Electricity & 44.0 & & 9.0 & 6.3 & 6.5 & 65.8 & 4.8 \\
\hline Processing inputs & 14.0 & & 30.6 & 3.6 & 11.0 & 59.2 & 4.3 \\
\hline Packaging inputs & 197.5 & & 53.2 & 31.8 & 94.0 & 376.5 & 27.3 \\
\hline Storage & 5.2 & & NA & & & 5.2 & 0.4 \\
\hline Other & 6.8 & & & & & 6.8 & 0.5 \\
\hline Processing sub-total & 414.7 & & 144.2 & 179.1 & 137.6 & 875.6 & 63.4 \\
\hline Trucks/lorries & 30.9 & & & 187.2 & 12.0 & & \\
\hline Railways & 44.8 & 173.1 & & 2.2 & 5.1 & 455.3 & 33.0 \\
\hline Transport sub-total & 75.6 & 173.1 & NA & 189.5 & 17.1 & 455.3 & 33.0 \\
\hline Total imported inputs & $1,160.0$ & 641.0 & 144.2 & 669.1 & 354.7 & $2,969.1$ & 215.1 \\
\hline Value of commodities & $8,545.1^{b}$ & $1,902.0^{c}$ & $2,407.0^{\mathrm{d}}$ & $2,276.6^{\mathrm{e}}$ & $\mathrm{NA}^{\mathrm{f}}$ & NA & $\mathrm{NA}$ \\
\hline $\begin{array}{l}\text { Average import } \\
\text { content }\end{array}$ & $14 \%$ & $34 \%$ & $6 \%$ & $30 \%$ & NA & NA & NA \\
\hline
\end{tabular}

Notes:

Columns may not tally due to Rounding

a Exchange Rate end December 1983 K Sh $13.80=$ US $\$ 1.0$.

b Value fob: coffee, tea, horticulture, tinned pineapples, sisal, pyrethrum, cashewnuts, wattle extract.

c Value ex-store NCPB maize; value into-store/mill wheat, barley, rice.

d Value ex-factory.

e Value ex-factory: sugar; oilseeds; tobacco; cotton

f Animal drugs and medicines, hides and skins imported; canned meat (KMC); milk products (KCC).

$\mathrm{g}$ Includes milling of both domestic production and imported cereals for human and animal consumption. 


\begin{tabular}{|c|c|c|c|}
\hline \multirow[b]{2}{*}{ Item } & \multicolumn{2}{|c|}{ Value of Imported Inputs } & \multirow[b]{2}{*}{$\begin{array}{l}\text { Coverage } \\
\text { per cent }\end{array}$} \\
\hline & $\begin{array}{c}\text { Selected } \\
\text { Cash Crops }\end{array}$ & $\begin{array}{l}\text { All Cash } \\
\text { Crops }^{\mathrm{b}}\end{array}$ & \\
\hline & \multicolumn{2}{|c|}{$K$ shillings million } & per cent \\
\hline \multicolumn{4}{|l|}{ Fertilizer } \\
\hline Maize & 117.5 & & \\
\hline Coffee & 85.6 & & \\
\hline Wheat & 77.1 & & \\
\hline Tea & 74.2 & & \\
\hline Sugar & 55.0 & & \\
\hline Total & 409.4 & 477.3 & 85.8 \\
\hline \multicolumn{4}{|l|}{ Agro-chemicals } \\
\hline Coffee & 242.0 & & \\
\hline Dairy and livestock & 200.0 & & \\
\hline Wheat & 50.0 & & \\
\hline Total & 492.0 & 629.3 & 78.2 \\
\hline \multicolumn{4}{|c|}{ Farm machinery and vehicles, petrol and oil } \\
\hline Sugar & 168.7 & & \\
\hline Coffee & 73.9 & & \\
\hline Wheat & 41.6 & & \\
\hline Maize & 45.8 & & \\
\hline Total & 330.0 & 433.5 & 76.1 \\
\hline \multicolumn{4}{|l|}{ Processing machinery } \\
\hline Sugar & 93.5 & & \\
\hline Maize milling & 33.7 & & \\
\hline Coffee & 22.1 & & \\
\hline Tea & 25.2 & & \\
\hline Total & 174.5 & 238.2 & 73.3 \\
\hline \multicolumn{4}{|l|}{ Fuel oil } \\
\hline Tea factories & 58.6 & & \\
\hline Sugar factories & 27.4 & & \\
\hline Total & 86.0 & 124.2 & 69.2 \\
\hline
\end{tabular}




\begin{tabular}{|c|c|c|c|}
\hline $\begin{array}{l}\text { Packaging } \\
\text { Canned pineapples } \\
\text { Milk - KCC } \\
\text { Maize milling } \\
\text { Horticulture }\end{array}$ & $\begin{array}{r}131.4 \\
81.7 \\
32.0 \\
21.0\end{array}$ & & \\
\hline Total & 266.1 & 376.5 & 70.7 \\
\hline $\begin{array}{l}\text { Transport } \\
\text { Sugar cane to factories } \\
\text { Maize - farm to NCPB depot } \\
\text { Maize - between NCPB depots } \\
\text { Coffee and NCPB stores }\end{array}$ & $\begin{array}{r}170.7 \\
26.2 \\
116.0 \\
35.7\end{array}$ & & \\
\hline Total & 348.6 & 455.3 & 76.6 \\
\hline Grand Total & $2,106.6$ & $2,969.1$ & 71.0 \\
\hline
\end{tabular}

Source: Table 1.

processing and transport of tea, have been expressed as a share of the value of smallholder and estate tea production valued at the Mombasa auction price averaged over the three previous years, 1980/81, $1981 / 82$ and $1982 / 83$.

Throughout the study, all imported inputs were estimated at domestic prices using the official exchange rate, and not at world prices or using a shadow exchange rate. This approach has the advantage that it is much easier to calculate imported input costs in domestic prices than 'world prices', and estimates measured in local prices at the official exchange rate can be readily checked by those familiar with local suppliers and producers. It has already been noted that the Kenyan exchange rate was not seriously overvalued in $1983 / 84$.

Although this direct approach is helpful in identifying the major imported inputs and measuring the average import content of agricultural commodities, it does not purport to measure the opportunity cost of saving or earning foreign exchange.

From the summary of imported inputs in Table 1, we see that around 40 per cent of all fertiliser was used on export crops, and the remaining 60 per cent went for cereals and other domestic cash crops. Further information provided in Table 2 indicates that maize accounted for one-quarter of all foreign exchange spent on fertiliser. For those readers particularly interested in the quantity and pattern of fertiliser consumption in Kenya, details are provided in Appendix Table 1 .
Among the imported agricultural inputs covered in the study, the largest single item was agro-chemicals, of which two-thirds was used on crops and one-third was spent on animal drugs and medicines. Domestic crops were not major users of agro-chemicals, and coffee exports accounted for over half of all foreign exchange spent on agro-chemicals. This estimate is based on annual field surveys of coffee cooperatives and estates carried out by the Coffee Research Foundation. A survey of agro-chemicals sales conducted by a leading distributor also found that coffee accounted for over half the total value of agrochemical sales in Kenya.

Turning to the foreign exchange costs of farm machinery, spare parts, depreciation, petrol and oil, it was estimated that the imported inputs used in the production of sugar cane and its transportation to the sugar factories far exceeded the combined costs of farm machinery for maize, wheat and coffee production.

The packaging of agricultural commodities is a major foreign exchange item, due partly to the generally high average import content of metal tins ( 65 per cent), plastic containers and sacks (55 per cent), paper cartons ( 50 per cent) and jute gunny bags ( 36 per cent). From Table 2 we find that the largest packaging items were tin cans for pineapple exports and plastic coated paper used in $\mathrm{KCC}$ milk packaging.

Transportation is clearly a major foreign exchange item, with the cost of movement of all agricultural commodities placed at around Shs $455 \mathrm{mn}$, a figure 
which includes rail and road transport into-store, to the factory, and to the port. Important for policy purpose was the finding that transport cost for shipping domestic cereals and other crops into-store and intofactory were five times greater than the costs of transporting all export crops from the factory to the port. Moreover, one quarter of the total transport bill stemmed from the cost of transferring maize between National Cereals and Produce Board depots in surplus and deficit areas. Maize and other domestic food crops are relatively bulky and have a low value per ton. This fact underlies the importance of moving away from a pan-territorial system of official producer prices towards a regional pricing system where price differentials would encourage the free movement of crops between food surplus and food deficit areas.

\section{The Average Import Content of Food and Non-food Crops}

For policy purposes we are interested not only in the absolute size of agricultural foreign exchange inputs, but also in their size relative to the value of production. The average import intensity shows the value of foreign exchange inputs expressed as a percentage of the value of each commodity, and is a concept more readily understood than the notion of domestic resource costs. It is straightforward to calculate using local financial data, and does not involve spurious world price comparisons or questionable shadow price assumptions.

Table 3 provides details of the average foreign exchange content of imported inputs used in export crops, cereals, milling, other domestic crops, dairy and livestock. Smallholder export crops predominated among those cash crops with the lowest average import content, with smallholder coffee, processed cashewnuts and pyrethrum extract having an average import content of around six to seven per cent of the ex-factory value. However, three estate crops - wattle extract, sisal and tea - were also low in terms of their relative use of foreign exchange inputs. Excluding foreign profits and dividends, the average import content of these three estate export commodities was around 8-10 per cent of the ex-factory value. Estate coffee and smallholder tea were similar in terms of their import content - both had an average import intensity of 15 per cent of the ex-factory value.

Consequently, there remains some ambiguity as to whether or not the average import content is generally lower for commodities grown on smallholdings than on estates, and much depends upon whether the estates are locally or foreign-owned. Among the export crops, canned pineapples, which are grown on a large foreign-owned estate, had the highest import intensity, estimated at around 34 per cent of the exfactory value, excluding export compensation subsidies and the repatriation of profits and dividend. At a considerable distance followed horticultural exports from large holdings, with an import content of around 22 per cent of the ex-store value. Surprisingly, the import content of smallholder tea was higher than that of estate tea and also noticeably higher than that of smallholder coffee, which had the lowest average import content of all commodities listed in Table 1. Whereas the tea estates used eucalyptus firewood from their forests to provide most of the fuel energy required for tea processing, the Kenya Tea Development Authority (KTDA) smallholder tea factories spent some Shs $47 \mathrm{mn}$ on imported oil for fuel energy in $1983 / 84$. This raises a number of policy issues, among them the total acreage that should be licensed for tea planting in smallholder areas and on estates, and the opportunity cost of land for growing firewood or crops.

One of the major findings to emerge from the study was the big difference between export crops and domestic food crops in terms of the average import content. Overall, the import content of export crops was found to be much smaller ( 13 per cent of the ex-store value) than that of domestic crops ( 32 per cent of the ex-store or ex-factory value). Wheat, barley and sunflower oil had the highest import intensities. The foreign exchange inputs for processing and transporting wheat and barley accounted for 40 per cent and 38 per cent respectively of the into-store value, while imported inputs for the production, transport and processing of sunflower oil formed 37 per cent of the ex-factory value. All three are domestic crops grown on large-scale mechanised farms in areas of high-potential land.

Other domestic food crops were also found to have a relatively high import content. Foreign exchange inputs used in the production, transport to factory and processing of sugar cane accounted for 32 per cent of the ex-factory value of sugar, excluding excise duties. The import content of maize purchases by the National Cereals and Produce Board from large scale mechanised farms was considerably higher than those from smallholdings. The large scale farming areas of Uasin Gishu, Trans Nzoia, parts of Nakuru, Nandi and Kericho were estimated to produce around 45 per cent of all NCPB maize purchases in $1983 / 84$, and the average import content, assuming a generous yield of 60 bags per hectare, was estimated at 35 per cent of the into-store price. Purchases from small mechanised farms, with a high yield of 45 bags per hectare, had an import content estimated at 32 per cent of the intostore value; and for small non-mechanised farms producing the national average of around 24 bags per hectare, the average import content fell to 20 per cent of the into-store value. Overall, maize purchases by the NCPB were estimated to have an average import intensity of 32 per cent of the ex-store price. 


\begin{tabular}{|c|c|c|c|c|}
\hline \multirow[b]{2}{*}{ Commodities } & $\begin{array}{l}\text { Value of } \\
\text { Imported }\end{array}$ & $\begin{array}{l}\text { Value of } \\
\text { Agricultural }\end{array}$ & \multicolumn{2}{|c|}{$\begin{array}{l}\text { Average Import } \\
\text { Content }\end{array}$} \\
\hline & million & $\begin{array}{l}\mathrm{N} \text { sis } \\
\text { million }\end{array}$ & per cent & per cent \\
\hline Export crops & $f o b^{\mathrm{a}}$ & $f a b$ & $f o b$ & ex-store \\
\hline $\begin{array}{c}\text { Coffee smallholders } \\
\text { estates } \\
\text { total }\end{array}$ & $\begin{array}{l}190.5 \\
322.9 \\
513.3\end{array}$ & $\begin{array}{l}2,737.4 \\
1,988.8 \\
4,726.2\end{array}$ & $\begin{array}{r}7 \\
16 \\
11\end{array}$ & $\begin{array}{r}6 \\
15 \\
10\end{array}$ \\
\hline $\begin{array}{ll}\text { Tea smallholders } \\
\text { estates } \\
\text { total }\end{array}$ & $\begin{array}{l}147.5 \\
129.9 \\
277.4\end{array}$ & $\begin{array}{r}932.5 \\
1,161.4 \\
2,093.9^{b}\end{array}$ & $\begin{array}{l}16 \\
11 \\
13\end{array}$ & $\begin{array}{l}15 \\
10 \\
12\end{array}$ \\
\hline $\begin{array}{l}\text { Horticulture } \\
\text { Cut flowers } \\
\text { French beans } \\
\text { total }\end{array}$ & $\begin{array}{l}25.4 \\
16.6 \\
83.8\end{array}$ & $\begin{array}{r}111.6 \\
78.0 \\
383.0\end{array}$ & $\begin{array}{l}23 \\
21 \\
22\end{array}$ & $\begin{array}{l}22 \\
20 \\
21\end{array}$ \\
\hline Canned pineapples & 219.0 & 619.9 & 35 & 34 \\
\hline Sisal & 37.6 & 356.9 & 11 & 10 \\
\hline Pyrethrum extract & 15.1 & 200.7 & 8 & 7 \\
\hline Cashewnuts & 8.2 & 102.1 & 8 & 7 \\
\hline Wattle extract & 5.6 & 62.4 & 9 & 4 \\
\hline Fotal export crops & $1,160.0$ & $8,545.1$ & 14 & 13 \\
\hline Cereal production & in-store ${ }^{c}$ & in-store & & in-store \\
\hline Wheat & 230.3 & 575.0 & & 40 \\
\hline Barley & 27.7 & 72.0 & & 38 \\
\hline Rice & 12.1 & 103.0 & & 12 \\
\hline \multicolumn{5}{|l|}{ Maize purchases by $\mathrm{NCPB}^{\mathrm{d}}$} \\
\hline large farms & 138.7 & 398.2 & & 35 \\
\hline small mechanised & 54.9 & 171.9 & & 32 \\
\hline small unmechanised & 61.2 & 303.4 & & 20 \\
\hline total - into store & 254.8 & 873.5 & & 29 \\
\hline total - ex-store & 370.9 & $1,152.0$ & & 32 \\
\hline Total cereals & $641.0^{\mathrm{e}}$ & $1,902.0$ & & 34 \\
\hline Cereal milling & ex-milf & ex-mill & & ex-mill \\
\hline Maize & 69.7 & $1,000.0$ & & 7 \\
\hline Wheat & 39.0 & 978.0 & & 4 \\
\hline Animal feeds & 35.5 & 240.0 & & 15 \\
\hline Total cereal milling & 144.2 & $2,407.0$ & & 6 \\
\hline
\end{tabular}




\begin{tabular}{|c|c|c|c|c|}
\hline Other domestic crops & ex-store & ex-store & & ex-store \\
\hline Sugar & 561.2 & $1,781.0$ & & 32 \\
\hline \multicolumn{5}{|l|}{ Oil seeds } \\
\hline maize oil & 10.6 & 46.0 & & 23 \\
\hline sunflower oii & 17.9 & 48.6 & & 37 \\
\hline total & 28.5 & 94.6 & & 30 \\
\hline Tobacco & 37.4 & 192.0 & & 19 \\
\hline Cotton lint & 42.0 & 209.0 & & 20 \\
\hline Total other domestic crops & 669.1 & $2,276.6$ & & 29 \\
\hline \multicolumn{5}{|l|}{ Dairy and livestock } \\
\hline Animal drugs and medicines & $200.0^{\mathrm{h}}$ & NA & & $\mathrm{NA}$ \\
\hline Milk products $-\mathrm{KCC}$ & $110.8^{i}$ & $1,186.1$ & ex-store & 9 \\
\hline Canned meat - KMC & $32.9^{i}$ & 192.2 & fob & 17 \\
\hline Hides and skins exported & $11.0^{\mathrm{j}}$ & 68.0 & fob & 16 \\
\hline Total dairy and livestock & 354.1 & NA & & NA \\
\hline Grand total & $2,969.1$ & NA & & NA \\
\hline
\end{tabular}

\section{Notes:}

a production, processing and transport from store to fob

b average fob price of tea $1980 / 81,1981 / 82,1982 / 83$

c production and transport into store

d National Cereals and Produce Board purchases estimated: large farms (2.520 million bags) small mechanised farms (1.088 million bags) small unmechanised (1.920 million bags)

e includes transport between NCPB stores estimated at Kshs $116 \mathrm{mn}$

r transport from NCPB store to mill; and processing

$\mathrm{g}$ production, transport into factory and processing

$h$ production

i transport and processing

$j$ processing and transport fob

Source: Table 1

Finally, not only was the average import content of export crops far lower than that of domestic food crops, but the gross income per hectare from export crops was considerably higher than that from domestic cereals and sugar. The average value per hectare of smallholder coffee and smallholder tea was around Shs 27,000 in 1983/84, whereas domestic sugarcane out growers received only around Shs 13,000 per hectare per year, and maize farms yielding the national average of 24 bags per hectare would have earned a gross value of only Shs 3,800 per hectare. Similar conclusions as to the higher average value per hectare of export crops than domestic food crops emerge from Table 4, which includes marketed and non-marketed agricultural production and covers not only smallholders but also estates and other large farms. It shows that export crops accounted for around 35 per cent of the total value of agricultural production, and the average value per hectare was ten times greater than for domestic food crops.

\section{The Net Foreign Exchange Earnings of the Agricultural Sector}

The net foreign exchange contribution of the agricultural sector towards the balance of payments, shown in Table 5, is a useful concept around which to discuss macro management and the interdependence between cash crops for export and domestic use. Agricultural exports provided two-thirds of total visible export earnings in $1983 / 84$, boosted by record 


\begin{tabular}{|c|c|c|c|}
\hline \multirow[b]{2}{*}{ Commodity } & \multirow{2}{*}{$\frac{\text { Value }^{\mathrm{a}}}{\text { \% of total }}$} & \multicolumn{2}{|c|}{ Value per hectare } \\
\hline & & $K$ shs $/ H A$ & Rank \\
\hline \multicolumn{4}{|l|}{ Export crops } \\
\hline coffee & 21.6 & 29,780 & (1) \\
\hline & 11.9 & 26,500 & (2) \\
\hline pyrethrum & 0.4 & 8,380 & (6) \\
\hline cashewnuts & 0.4 & 3,240 & (11) \\
\hline sisal & 1.1 & 2,740 & (14) \\
\hline total export crops & 35.4 & 27,295 & \\
\hline \multicolumn{4}{|c|}{ Other export and domestic crops ${ }^{b}$} \\
\hline vegetables & 3.4 & 18,260 & (3) \\
\hline tobacco & 0.5 & 17,700 & (4) \\
\hline fruits & 3.1 & 5,920 & (7) \\
\hline cotton & 0.4 & 640 & (18) \\
\hline total other crops & 7.4 & 12,100 & \\
\hline \multicolumn{4}{|l|}{ Domestic food crops } \\
\hline rice & 0.5 & 10,380 & (5) \\
\hline barley & 0.4 & 4,980 & (8) \\
\hline root crops ${ }^{\mathrm{c}}$ & 8.1 & 4,100 & (9) \\
\hline wheat & 2.1 & 3,820 & (10) \\
\hline maize and beans ${ }^{d}$ & 16.6 & 3,060 & (12) \\
\hline sunflower & 0.2 & 2,820 & (13) \\
\hline groundnuts & 0.2 & 1,680 & (15) \\
\hline & 16.3 & 1,460 & (16) \\
\hline sorghum and millet & 1.5 & 960 & (17) \\
\hline total food crops & 45.9 & 2,730 & \\
\hline $\begin{array}{l}\text { sugar } \\
\text { beef } \\
\text { sheep and goats } \\
\text { others }\end{array}$ & 11.2 & NA & \\
\hline Total & 100.0 & $13,315^{\mathrm{e}}$ & \\
\hline
\end{tabular}

Notes:

a Total value of Kshs $20,700 \mathrm{mn}$

b vegetables and fruits are both for export and domestic food consumption; tobacco and cotton are domestic non-food crops c includes potatoes

d because beans are typically interplanted with maize

e excludes sugar, beef, sheep and goats and others

Source: Republic of Kenya, Sessional Paper No. I of 1986, on 'Economic Management for Renewed Growth', Government Printer, Nairobi, 1986, Table 5.1, page 64. 
Visible exports

$\mathrm{K}$ shillings million

agriculture

non-agriculture

total

Visible imports

$$
\begin{array}{r}
\text { agriculture } \\
- \text { inputs } \\
- \text { food } \\
- \text { total }
\end{array}
$$

non-agriculture

total

Visible balance

agriculture - net foreign exchange surplus

non-agriculture - net foreign exchange deficit

total - Balance of Trade

Invisible balance

of which: Tourism and travel

Government transfers and foreign grants

Capital movements (net)

short term borrowing

private long term borrowing

government long term borrowing

government corporations

total

\section{Summary items}

1 Net foreign exchange surplus of agriculture as percent of non-agriculture imports

2 Gap to be funded from:

manufacturing exports and tourism;

foreign grants; private inflows;

external borrowing; change in reserves

Source: Table 1 Statistical Abstract 


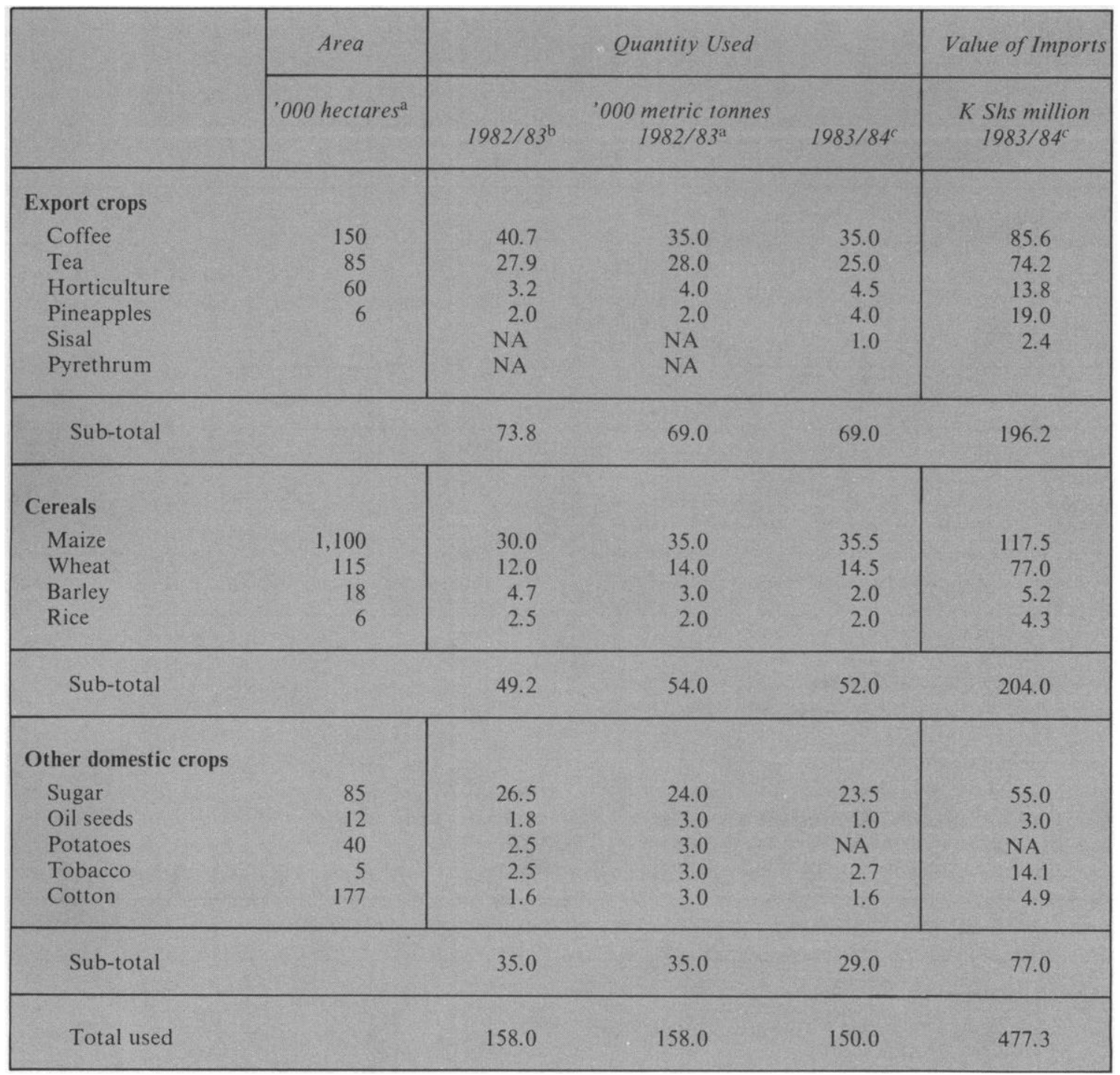

Notes/Sources:

a Chemical Engineering Consultants (1984)

b Michael Schluter and George Riugu (1985)

c Own calculations - Table 1 
prices for tea, and a record level of coffee production. On the other hand, imported inputs for the production, processing and transport of all agricultural commodities totalled Kshs $2,696 \mathrm{mn}$ and the cost of food imports was Ksha $1,853 \mathrm{mn}$, a figure which was unusually high on account of the drought which affected parts of the country in the latter part of 1984 . Nevertheless, in 1983/84 the largest imported single food item was not maize, but animal and vegetable oils used in domestic cooking.

After deducting imported agricultural inputs and food items from the value of agricultural earnings, the net foreign exchange surplus of agriculture was estimated at Shs $4,588 \mathrm{mn}$ in $1983 / 84$. This financed only 29 per cent of visible imports by the rest of the economy, and left 71 per cent of the non-agricultural import bill to be financed from elsewhere. The manufacturing sector is not a net earner of foreign exchange in the accounting sense, and as Table 5 shows, the net foreign exchange deficit of the non-agricultural sector in 1983/84 was Kshas $11,430 \mathrm{mn}$. Kenya's balance of payments is heavily dependent upon foreign exchange inflows from tourism, foreign aid, private capital inflows and external borrowing which can be more unreliable than the weather, and are less reponsive to government policies than is the pattern and level of production from agriculture and agro-processing activities. If the production of basic food stuffs, such as maize, milk and meat is to keep pace with the rapid growth of population, Kenya must earn more foreign exchange with which to finance imported inputs needed for the production, processing and transport of agricultural commodities. Moreover, as real incomes rise, the demand for imported items by the non-agricultural sector tends to rise more than proportionately, and it is to agricultural and processed agricultural exports that Kenya is likely to turn for the foreign exchange earnings needed to finance the balance of payments [Sharpley and Lewis, 1988].

\section{References}

Chemical Engineering Consultants Nairobi (1984), Proceedings of Workshop on the Fertilizer Infrastructure Support Project, November, (mimeo)

\section{Pick's Currency Year Book 1984}

Republic of Kenya, Statistical Abstract, (annual) Government Printer, Nairobi

Schluter, Michael and George Riugu, 1985, 'Fertilizer and Seed Requirements in Kenya from 1982/83 to 1990/91', IBRD, Agricultural Inputs Revien', Annex 1, (mimeo)

Sharpley, Jennifer, 1986, Economic Policies and Agricultural Performance: the case of Kenya, OECD Development Centre Papers, Paris

Sharpley, Jennifer and Stephen R. Lewis Jr, 1988, 'Kenya's Industrialisation, 1964-84', IDS Discussion Paper No 242, February 